Review

\title{
Comparative Histological Study between the Effect of Calcitonin versus Hormonal Replacement Therapy on Cartilage of Knee Joint of Ovariectomized Albino Rat
}

\author{
Article Faten Riad Omar Osman ${ }^{1}$, Mira Farouk Youssef Yacoub ${ }^{1}$, Samraa Hussein Abdel- \\ Kawi Mohammed ${ }^{2}$ Ola Esmail Mogahed El Sayed ${ }^{2}$
}

Department of Histology, Faculty of Medicine, ${ }^{1}$ Cairo University, ${ }^{2}$ Beni-Suef University

\begin{abstract}
Background: Osteoarthritis (OA) is the most common age-related joint degenerative disease, which is associated with post menopausal females.

Aim of Work: To compare the effect of hormonal replacement therapy (HRT) (Oestrogen and Progesterone) versus calcitonin administration on articular cartilage of the knee joints in murine model of osteoarthritis induced by ovariectomy.

Materials and Methods: Thirty six adult female rats were divided into five groups. Group I: control; Group II: sham operated; Group III: ovariectomized rats: Group IV: ovariectomized then received HRT $) 1 \mathrm{ml} / \mathrm{kg}(0.2 \mathrm{ml}) /$ day IM ((for 8 weeks); GroupV: ovariectomized then received calcitonin $) 2 \mathrm{IU} / \mathrm{kg} /$ day $(0.04 \mathrm{ml}) \mathrm{SC}$ ( (for 8 weeks). The rats of each group were sacrificed after 8 weeks. Articular cartilage of knee joints were processed and stained with Haematoxylin and Eosin, Alcian blue, PAS, immunohistochemical staining of Bcl-2 and statistical analysis were applied.

Results: Ovariectomy resulted in degeneration, apoptosis and deterioration of normal structure of articular cartilage, with decreased PAS reaction, decreased Alcian blue staining, and weak immunoreactivity for Bcl-2 when compared with the control and sham operated groups. Calcitonin and HRT supplementation after ovariectomy mostly prevented these changes. Conclusion: It could be concluded that OVX causes severe changes in articular cartilage and these changes are more evident with time. HRT had a significant effect in prevention of cartilage degradation in OVX model of OA. Calcitonin administration greatly improves the histological architecture of the articular cartilage. So calcitonin had a significant effect in prevention of cartilage degradation in OVX model of OA. It can be considered as a potential therapeutic agent in OA.
\end{abstract}

Received: 15 January 2019, Accepted: 23 February 2019

Key Words: Bcl-2, calcitonin, cartilage, HRT, osteoarthritis, ovariectomy.

Corresponding Author: Ola Esmail Mogahed El Sayed, MD, Department of Histology, Faculty of Medicine, Beni-Suef University, Cairo, Egypt, Tel.: +20 1013532213, E-mail: olaarwa@yahoo.com

ISSN: $1110-0559$, Vol. 42, No. 3

\section{INTRODUCTION}

Osteoarthritis (OA) is the most common age-linked joint pathology degenerative disease with progressive destruction of articular cartilage and subchondral bone ${ }^{[1]}$. Beneath the age of 50 , male patients that tend to have more OA than females, but there is dramatic increase in females suffering from OA post menopausal ${ }^{[2]}$.

Ovariectomy (OVX) is counted as a good pattern of post menopausal osteoporosis. It has an adverse effect on the intrinsic material of the articular cartilage of the knee, resulting in accelerated cartilage degeneration and increased cartilage surface erosion ${ }^{[3]}$.

Studies have shown that hormone replacement therapy have inhibitory effects on the inflammatory and bone changes of $\mathrm{OA}^{[4]}$, but has some potential risks mainly breast cancer, venous thromboembolism, strokes, coronary heart disease and migraine ${ }^{[5]}$.

Calcitonin prohibits osteoclastic bone resorption and regulates calcium homeostasis of body ${ }^{[6]}$. In humans, pigs and salmon fish, calcitonin has been applied preferentially as a therapeutic factor because of its higher potency. Salmon calcitonin has a poweful anti-resorptive effect by direct binding to osteoclasts ${ }^{[7]}$. chondrocytes in articular cartilage respond directly to calcitonin as they have calcitonin receptors on their surfaces ${ }^{[8]}$.

Accordingly, this study was designed to compare the effect of hormonal replacement therapy (Oestrogen and Progesterone) versus calcitonin administration on articular cartilage of the knee joints in murine model of osteoarthritis induced by ovariectomy.

\section{MATERIALS AND METHODS}

\section{Drugs}

Hormone replacement therapy(trade name Mesocept)

Ampoule of (one $\mathrm{ml}$ ) contains $50 \mathrm{mg}$ norethisterone enanthate and $5 \mathrm{mg}$ estradiol valerate in oily solution (CID pharma, Giza- Egypt).

Calcitonin 50 STADA ampoule (one ml) contains 50IU calcitonin-Salmon/acetate (Global Napi Pharma, 6th of October City - Egypt). 


\section{Animals}

This study was performed on thirty six adult female albino rats. Their average age was 3-4 months (weighing 200-230 gm). The rats were bred at the Animal House of Kasr El-Aini, Faculty of Medicine, Cairo University. Every two animals were purchased and housed in a separate metal cage with mesh and wood chips for bedding. They were maintained in room temperature with a 12-hour light /dark cycle, fed with standard laboratory chow and had free access to tap water. Rats were randomly divided into 5 groups as following;

Group I: (Control) $n=6$ rats. The rats were sacrificed after 8 weeks. Control animals were injected with physiological saline $(0.5 \mathrm{ml} /$ day intraperitoneal $)$ per rat.

Group II: (Sham operated) $n=6$ rats. Rats were exposed to Sham operation. The rats were sacrificed after 8 weeks.

Group III: $\mathrm{n}=8$ rats. They were exposed to ovariectomy, and the animals were sacrificed after 8 weeks of ovariectomy ${ }^{[9]}$.

Group IV: $\mathrm{n}=8$ rats. Animals were exposed to ovariectomy then hormonal replacement therapy was given every day starting the day following ovariectomy. One $\mathrm{ml} /$ $\mathrm{kg}(0.2 \mathrm{ml}) /$ day $\mathrm{IM}$ per rat ${ }^{[5]}$. The rats were sacrificed after 8 weeks of ovariectomy and HRT.

Group V: $\mathrm{n}=8$ rats. Animals were exposed to ovariectomy then calcitonin was given starting day following ovariectomy. Two $\mathrm{IU} / \mathrm{kg} / \mathrm{day}(0.04 \mathrm{ml})$ per rat administrated $\mathrm{SC}^{[10]}$. The rats were sacrificed after 8 weeks of ovariectomy and calcitonin.

\section{Methods}

\section{Operation}

Ovariectomy (OVX): Each rat was anesthetized with light ether. The skin of rats was sterilized with Povidone Iodine Solution $(10 \mathrm{~g} / 100 \mathrm{ml})$. Long incision $(3 \mathrm{~cm})$ was made at the center area of lower half of the body and tail end and double dorsolateral in $\neg$ cision was made in the muscle. Once the abdominal cavity was opened, ovaries surrounded by body fat were found. The points where the fallopian tubes and the uterine horns meet were incised and ovaries were removed. Muscle ap $\neg$ proximation and skin closure were performed with catgut sutures. Postoperatively, gentamycin $(6 \mathrm{mg} / \mathrm{kg})$ was administered by intra $\neg$ muscular injection. After the surgery, all of the rats were allowed to move freely inside the metal cage ${ }^{[11]}$.

\section{Sham Operation}

The abdominal cavities of control rats were opened but their ovaries were left intact, just to be exposed to the same stress of the operation. The same antiseptic precautions and the same procedure of wound closure were followed as for the ovariectomy group.

\section{Dissection and processing of the samples}

Rats were sacrificed at the end of experimental periods by inhalation of over dose phenobarbitol ${ }^{[9]}$. Histological assessment was conducted on the whole-layer of cartilage sagittal section in knee joint including articular cartilage and its lower bone were fixed in $10 \%$ neutral buffered formalin for 72 hours. The specimens were placed in hydrochloric $(\mathrm{Hcl})$ acid solution $(5 \%)$ for decalcification. $\mathrm{HCl}$ solution was replaced daily until decalcifi $\neg$ cation process was completed ( 2 weeks). The specimens were completely washed off until the neutral-pH state after the decalcification. They were processed for paraffin sections. These were cut 5-6 $\mu \mathrm{m}$ thickness and were stained.

\section{Paraffin sections were subjected for the following} staining procedures;

1. Hematoxylin and Eosin (H\&E) to demonstrate the histological changes ${ }^{[12]}$.

2. Periodic Acid Schiff reaction (PAS) to demonstrate changes in matrix ${ }^{[13]}$.

3. Alcian blue stain to demonstrate changes in chondrocytes $^{[13]}$.

4. Immunohistochemical staining for BCL-2 (anti apoptotic) $)^{[14]}$.

\section{Immunohistochemical staining for BCL 2}

Monoclonal mouse BCL2 antibody (1/400 dilution), Clone 124, (Lab Vision Corporation laboratories, CA 94539, USA, catalogue number: 550847. Ultravision large volume detection system anti-polyvalent, HRP (ready to use) (Thermoscientific, catalogue number TP-060-HL) was used. Reagents supplied included serum blocking solution, biotinylated secondary antibody, streptavidinperoxidase conjugate, concentrated substrate buffer and its chromogen solution, hydrogen peroxide, hematoxylin solution, Histomount. To establish immunohistochemical staining specificity, negative control serial sections 8 were processed by replacing the primary antibody by phosphate buffer saline with all other steps performed in the same manner. Positive tissue control for BCL-2 immunostaining was rat tonsil with a brownish cytoplasmic immunoreaction,

\section{C-Morphometric Study}

Data were obtained using "Leica Qwin $500 \mathrm{C}$ " image analyzer computer system Ltd. (Cambridge, England) in Histology department, Faculty of Medicine, Cairo University. Images were captured live on to the screen from sections under light microscope with video camera. The image analyzer consisted of a color video camera, Olympus microscope, colored monitor, hard disc of IBM personal computer connected to the microscope and controlled by "Leica Qwin 500 C" software. Slides were examined under the light microscope. All measurements were taken in 5 non overlapping fields for each specimen for all groups.

\section{The following parameters were measured}

- The thickness of articular cartilage using 
"interactive Measurements" menu to measure distance in $\mu \mathrm{ms}$. This was observed at $\mathrm{x} 20$ objective lens. Five measures were taken and average calculated for each slide.

- The optical density of alcian blue reaction: Detection of the optical density of blue colour of stained sections was observed at x 40 objective lens. Grey measure menu was used to convert image and detect grey level of reaction and measure it in small frames.

- The optical density of PAS reaction: Detection of the optical density of red colour in PAS stained sections was observed at $\mathrm{x} 40$ objective lens. Grey measure menu was used to convert image and detect grey level of reaction and measure it in small frames.

- The reaction of BCL2 positive cells: was done by masking reaction with the binary colour to specify areas of brown reaction to be detected then measured at 40 objective lens.

\section{D-Statistical study ${ }^{[15]}$}

Quantitative data were summarized as means and standard deviations and Comparison between study groups was made using one analysis of variance (ANOVA) followed by post hoc Tukey test. $P$ values $<0.05$ were considered statistically significant and $<0.01$ highly significant. Calculations were made on SPSS software (version 16).

\section{RESULTS}

\section{1-Hematoxylin and Eosin stained tibial articular cartilage sections (plate1)}

Histological examination of rat tibial articular cartilage sections in both control and sham operated groups (GI, II) showed normal articular cartilage structure and smooth articular surface with no covering perichondrium. It showed oval chondrocytes in the superficial layer and round ones in groups in the deep layer, embedded in a homogenous matrix. The sections in groupIII $(\mathrm{OVX} / 8 \mathrm{w})$ revealed total disorganization. Most chondrocytes were disorganized, exhibited pyknotic nuclei in transitional and deep zones with areas of loss of matrix and others of heterogeneous matrix can be seen. The sections in groupIV (HRT /8w) appeared to have a smooth and thickened articular surface with organized articular cartilage. The sections of groupV (calcitonin $/ 8 \mathrm{w}$ ) appeared to have organization of its layers. The cartilage surface was smooth with oval chondrocytes in superficial layers and rounded in deep layers, embedded in a homogenous matrix.

\section{2- Alcian blue stained tibial articular cartilage sections (plate 2)}

Histological examination of both control and sham operated groups (GI, II) revealed obvious alcian blue staining in most chondrocytes. The sections of group III
(OVX /8w) showed weak staining in most chondrocytes. The sections of both groupIV (HRT $/ 8 \mathrm{w}$ ) and groupV (calcitonin $/ 8 \mathrm{w}$ ) showed moderate staining of some chondrocytes as compared to III.

\section{3- PAS stained tibial articular cartilage sections (plate 3)}

Histological examination in both control and sham operated groups (GI, II) revealed obvious PAS +ve reaction in their extracellular matrix. The sections of groupIII (OVX /8w) showed weak PAS +ve reaction in their extracellular matrix. While both groupIV (HRT /8w) and groupV (calcitonin $/ 8 \mathrm{w}$ ) showed moderate PAS $+\mathrm{ve}$ reaction in their extracellular matrix as compared to III.

\section{4-Immuno-Histochemical Results: (Bcl-2 staining) (plate 4)}

Histological examination of the sections in both control and sham operated groups GI, II revealed dense $+v e \mathrm{Bcl} 2$ immunoexpression in most chondrocytes. The sections in groupIII $(\mathrm{OVX} / 8 \mathrm{w})$ showed weak +ve $\mathrm{Bcl} 2$ immunoexpression in the cytoplasm of most chondrocytes. Group IV (HRT /8w) showed moderate positive inimmunoexpression in the cytoplasm of some chondrocytes as compared to G III. While groupV (calcitonin/8w) showed dense $+\mathrm{ve} \mathrm{Bcl} 2$ immunoexpression in the cytoplasm of most chondrocytes as compared to G III.

\section{II) Morphometric Results}

\section{1-Articular cartilage thickness ( $\mu \mathrm{m})$ of the studied groups of the experiment (Table 1 and Histogram 1)}

OVX group showed highly significant decrease in thickness of articular cartilage when compared to control group $(p<0.0001)$. Groups HRT and calcitonin showed significant increase in the thickness of articular cartilage when compared with group OVX $(p<0.0001)$. No significant difference was detected between groups HRT and calcitonin. However, both HRT and Calcitonin were still significantly lower than control.

2- Optical density of Alcian blue reaction in chondrocyte cytoplasm of the studied groups of the experiment (Table 2 and Histogram 2)

OVX group showed highly significant decrease in optical density of alcian blue reaction in chondrocyte cytoplasm when compared to control group $(p<0.0001)$.

Groups HRT and calcitonin showed significant increase when compared to group OVX $(p<0.0001)$. No significant difference was detected with the control group. No significant difference was detected between groups HRT and calcitonin.

\section{3- Optical density of PAS reaction in cartilage matrix of the studied groups after 8 weeks of the experiment (Table 3 and Histogram 3)}

OVX group showed highly significant decrease in optical density of PAS reaction in cartilage matrix when 
compared to control group ( $p<0.0001)$. Groups HRT and calcitonin showed significant increase when compared to group OVX $(p<0.0001)$. No significant difference was detected between groups HRT and calcitonin. Values for both groups were also significantly lower than control.

\section{4- Mean Area \% of Bcl-2 immunoreactivity in the} chondrocyte cytoplasm in the studied groups of the

\section{experiment (Table 4 and Histogram 4)}

OVX group showed highly significant decrease in the mean area $\%$ of Bcl-2 when compared to the control group ( $p<0.0001)$. Groups HRT and calcitonin showed significant increase when compared to group OVX. No significant difference was detected between groups HRT and calcitonin.

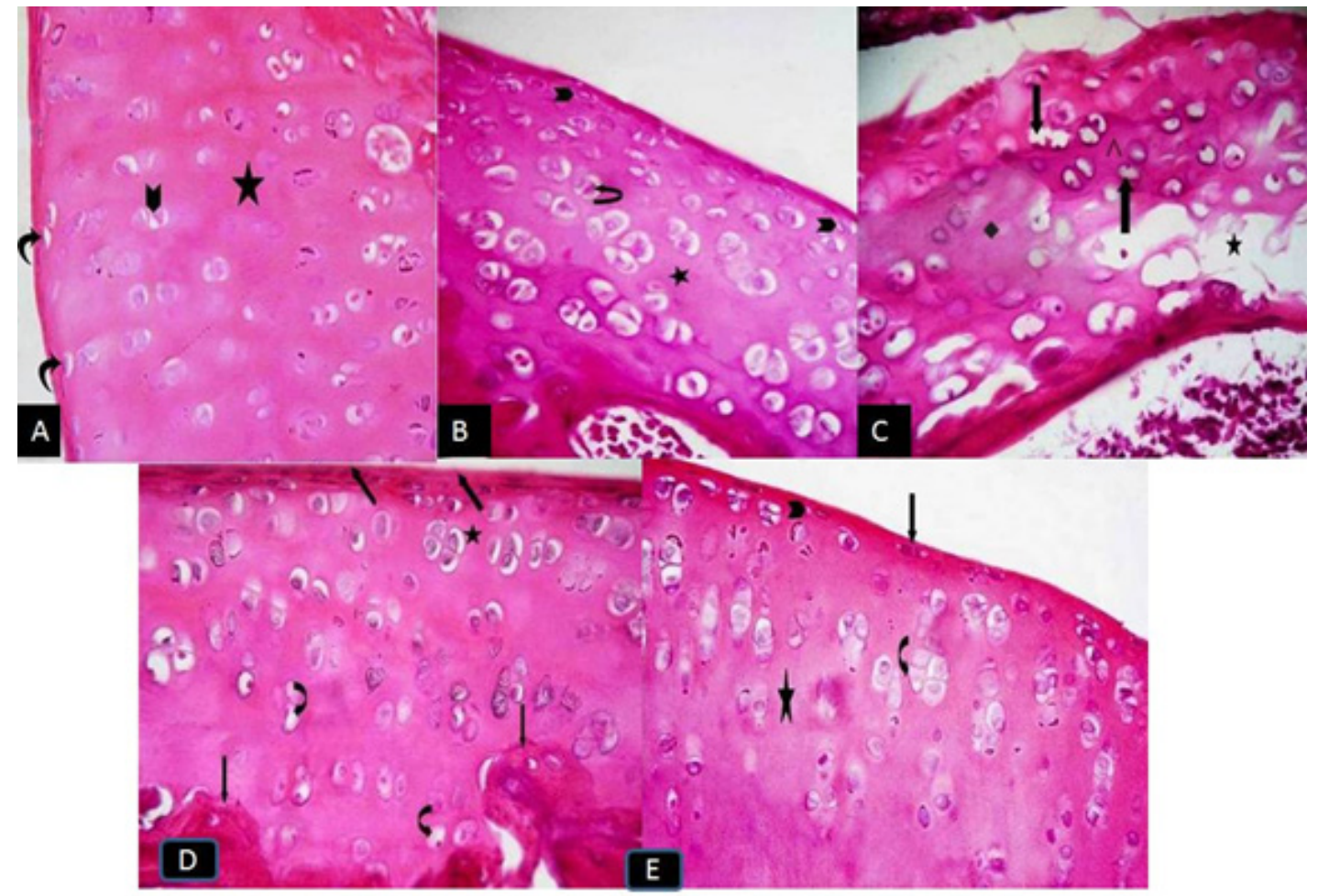

Plate 1: photomicrographs of articular cartilage of A (control group): showing oval chondrocytes in superficial layer (curved arrow), and rounded chondrocytes in deep layer (arrow head). Organized chondrocytes are seen in homogenous matrix (asterix). B (sham operated group): showing the oval chondrocytes in the superficial layer (arrow head) and round ones in the deep layers (curved arrow). Organized chondrocytes are embedded in a homogenous matrix (asterix). C (OVX group): Most chondrocytes are disorganized exhibit pyknotic nuclei (thick arrow). Obviously vacuolated matrix can be seen (asterix) with areas show heterogenous matrix (square) and others show homogenous matrix (arrow head). Note very thin plate of subchondral bone. D (HRT received group): showing a smooth thickened articular surface (thick arrows). Organized dividing chondrocytes are embedded in homogenous matrix. Few chondrocyts, limited to deep zone, exhibit pyknotic nuclei (curved arrow). E (calcitonin received group): showing a smooth thin articular surface (thin arrow). Organized chondrocytes are seen in homogenous matrix. (H\&E: A, B, C, D \& E x400). 


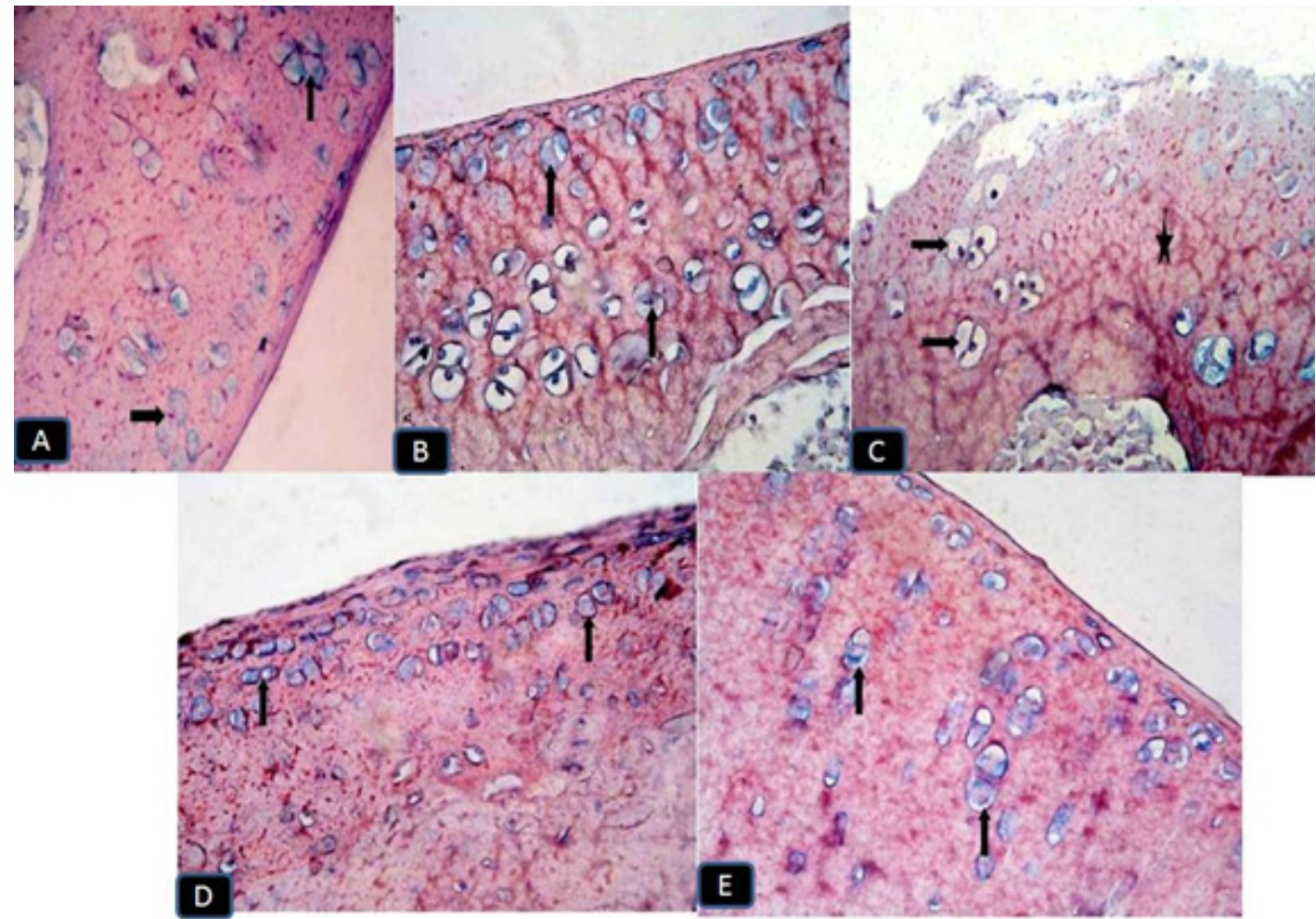

Plate 2: photomicrographs of articular cartilage stained with Alcian blue

A (Control group): showing obvious Alcian blue staining (arrows) in the cytoplasm of most chondrocytes. B (sham operated group): showing obvious Alcian blue staining (arrows) in the cytoplasm of most chondrocytes. C (OVX group): showing weak Alcian blue staining (arrows) in the cytoplasm of all chondrocytes. Note there is decreased cell population (asterix). D (HRT received group) showing moderate Alcian blue staining (arrows) in the cytoplasm of some chondrocytes. E (calcitonin received group) showing moderate Alcian blue staining (arrows) in the cytoplasm of some chondrocytes (Alcian blue: A, $\mathrm{B}, \mathrm{C}, \mathrm{D} \& \mathrm{E} \mathrm{x} 400)$.

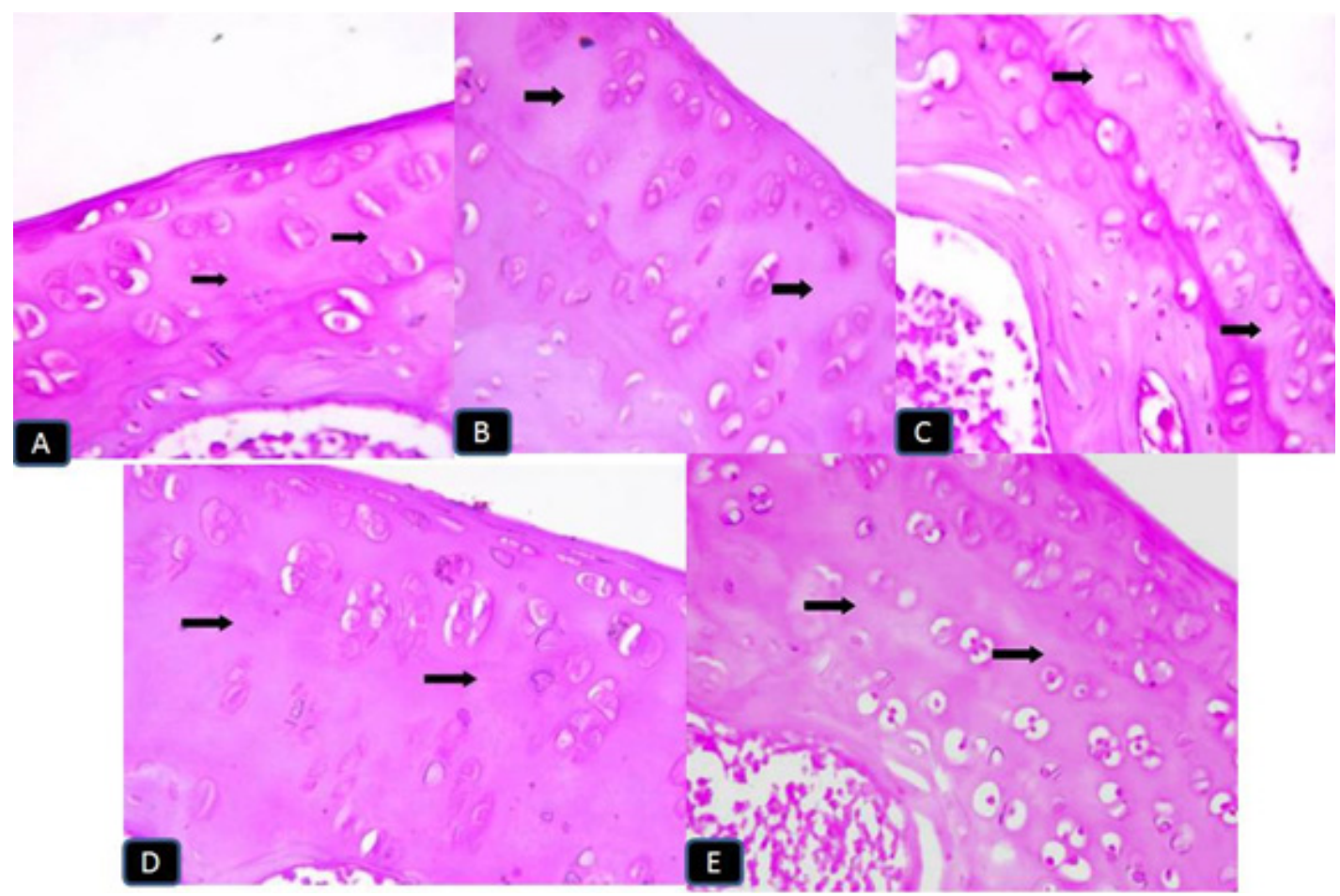

Plate 3: photomicrographs of articular cartilage stained with PAS. A (Control group): showing obvious PAS +ve reaction (arrows) in the matrix and chondrocytes. B (sham operated group): showing obvious PAS +ve reaction (arrows) in the matrix and chondrocytes. C (OVX group) showing weak PAS +ve reaction (arrows) in most of matrix. D (HRT received group): showing moderate PAS +ve reaction (arrows) in the matrix. E (calcitonin received group): showing moderate PAS +ve reaction (arrows) in the matrix. (PAS: A, B, C, D \& E x400). 


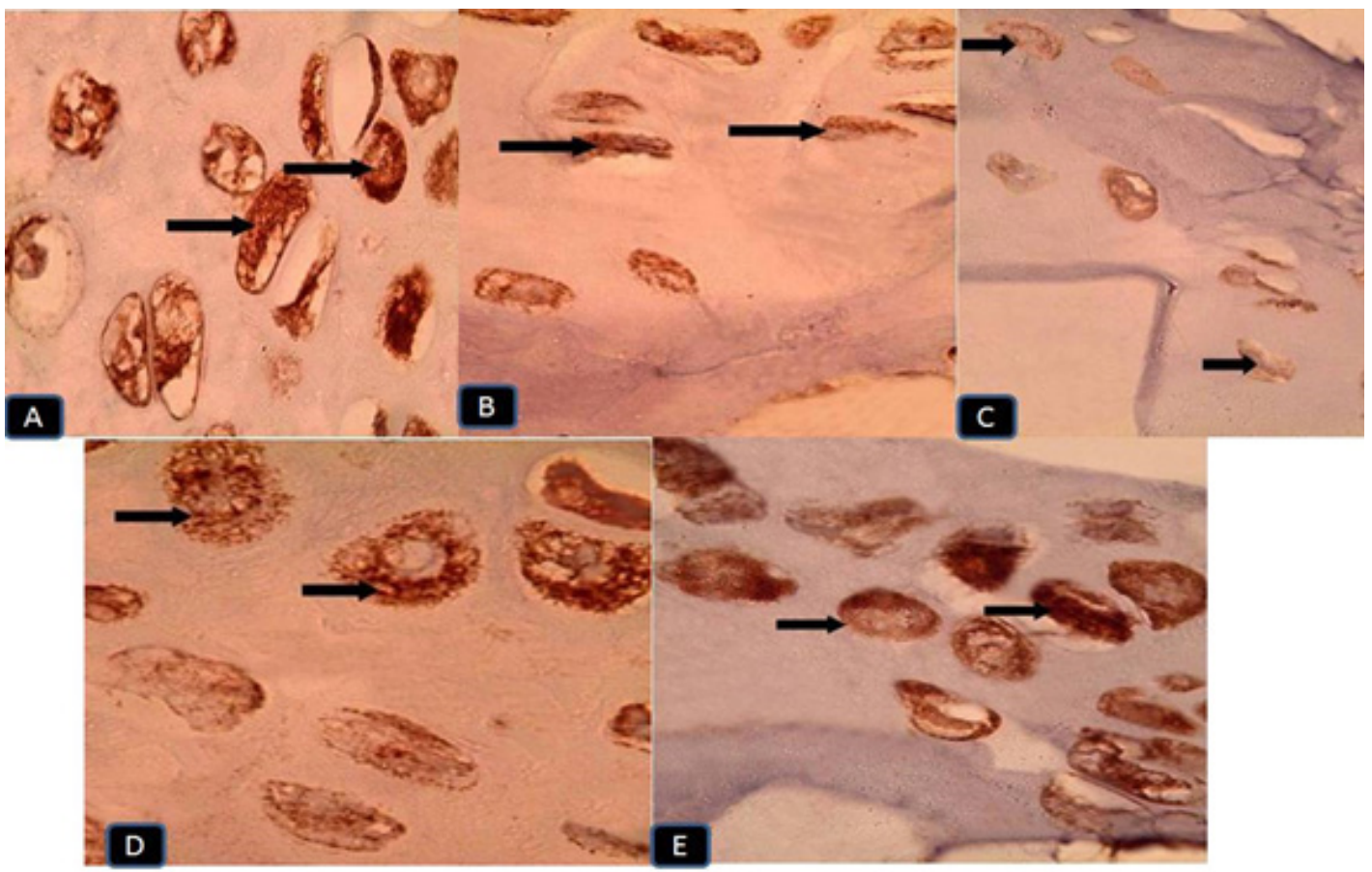

Plate 4: photomicrographs of articular cartilage immunostained with Bcl-2 showing: A (Control group): dense +ve Bcl-2 immunoexpression (I E) as granular deposits (arrows) filling the cytoplasm of most chondrocytes. Note that lacunae and matrix are -ve in staining. B (sham operated group: +ve Bcl-2 I E (arrows) filling the cytoplasm of most chondrocytes. Note that lacunae and matrix are -ve in staining. C (OVX group): weak +ve Bcl-2 I E (arrows) in the cytoplasm of most chondrocytes. D (HRT received group): moderate +ve Bcl-2 I E (arrows) in the cytoplasm of most chondrocytes. E (calcitonin received group): dense +ve Bcl-2 I E (arrows) in the cytoplasm of some chondrocytes. (Bcl-2 immunostaining: A, B, C, D \& E x1000).

Table 1: Comparison between thickness of the articular cartilage $(\mu \mathrm{m})$ of the studied groups of the experiment

\begin{tabular}{lccccc}
\hline \multirow{2}{*}{ Variables } & control & Sham & OVX & HRT & Calcitonin \\
\cline { 2 - 6 } & Mean \pm SD $(\mu \mathrm{m})$ & Mean $\pm \mathrm{SD}(\mu \mathrm{m})$ & Mean $\pm \mathrm{SD}(\mu \mathrm{m})$ & Mean $\pm \mathrm{SD}(\mu \mathrm{m})$ & Mean $\pm \mathrm{SD}(\mu \mathrm{m})$ \\
\hline thickness & $71.38 \pm 4.52$ & $70.15 \pm 3.67$ & $41.06 \pm 8.42^{*}$ & $63.77 \pm 10.12 \#$ & $66.25 \pm 10.91 \#$ \\
\hline
\end{tabular}

$p$ value is significant if $<0.05^{*}$

Table 2: Comparison between optical density of Alcian blue reaction in chondrocyte cytoplasm of the studied groups of the experiment

\begin{tabular}{lccccc}
\hline \multirow{2}{*}{ Variables } & control & Sham & OVX & HRT & Calcitonin \\
\cline { 2 - 5 } & Mean \pm SD & Mean \pm SD & Mean \pm SD & Mean \pm SD & Mean \pm SD \\
\hline optical density & $0.79 \pm 0.05$ & $0.78 \pm 0.04$ & $0.45 \pm 0.03 *$ & $0.76 \pm 0.04 \#$ & $0.77 \pm 0.05 \#$ \\
\hline
\end{tabular}

$p$ value is significant if $<0.05$

Table 3: Comparison between optical density of PAS reaction in cartilage matrix of the studied groups of the experiment

\begin{tabular}{lccccc}
\hline \multirow{2}{*}{ Variables } & control & Sham & OVX & HRT & Calcitonin \\
\cline { 2 - 5 } & Mean \pm SD & Mean \pm SD & Mean \pm SD & Mean \pm SD & Mean \pm SD \\
\hline Optical density & $0.99 \pm 0.06$ & $0.96 \pm 0.06$ & $0.75 \pm 0.04 *$ & $0.86 \pm 0.04 * \#$ \\
\hline$p$ value is significant if $<0.05$ & & & &
\end{tabular}

Table 4: Comparison between area $\%$ of Bcl-2 reaction in chondrocyte cytoplasm of the studied groups of the experiment

\begin{tabular}{lccccc}
\hline \multirow{2}{*}{ Variables } & control & Sham & OVX & HRT & Calcitonin \\
\cline { 2 - 5 } & Mean \pm SD & Mean \pm SD & Mean \pm SD & Mean \pm SD & Mean \pm SD \\
\hline Area $\%$ & $0.68 \pm 0.05$ & $0.67 \pm 0.05$ & $0.42 \pm 0.04 *$ & $0.62 \pm 0.07 \#$ & $0.65 \pm 0.05 \#$ \\
\hline
\end{tabular}

$p$ value is significant if $<0.05^{*}$ 


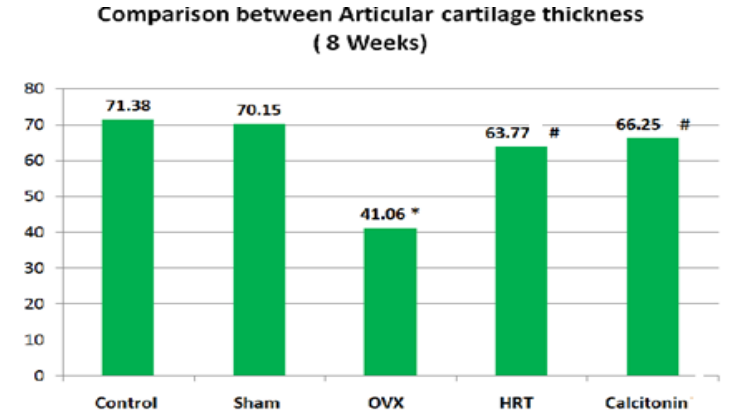

Histogram 1: Showing thickness of the articular cartilage of the studied groups

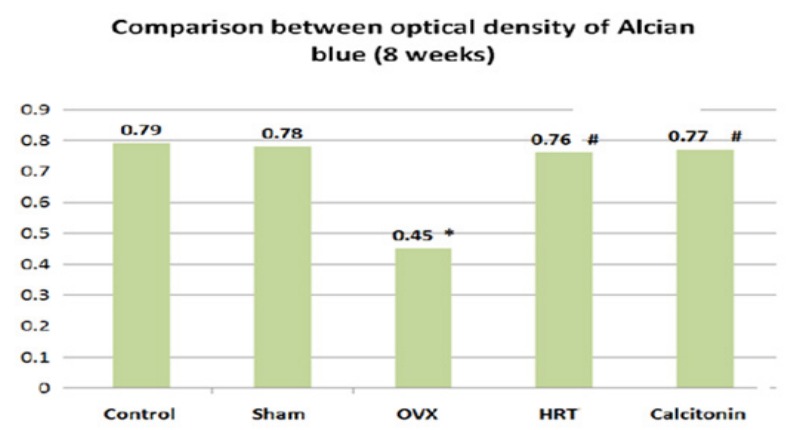

Histogram 2: Showing optical density of Alcian blue reaction in chondrocyte cytoplasm of the studied groups

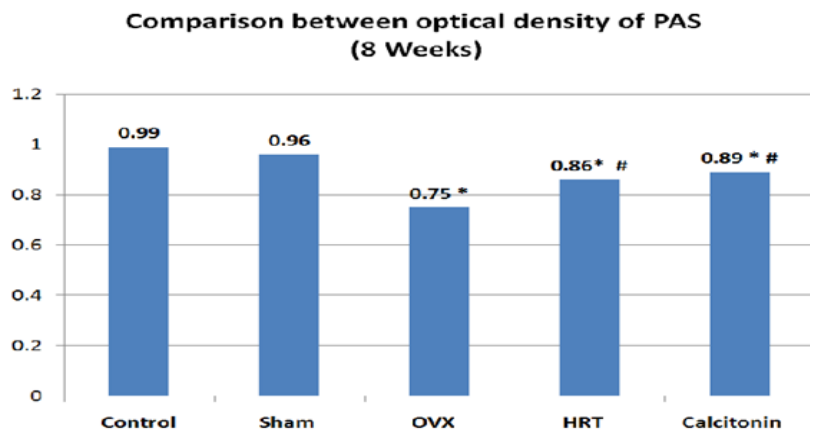

Histogram 3: Showing of optical density of PAS reaction in cartilage matrix of the studied groups

Comparison between Mean area \% of $\mathrm{Bcl} 2$ reaction (8 weeks)

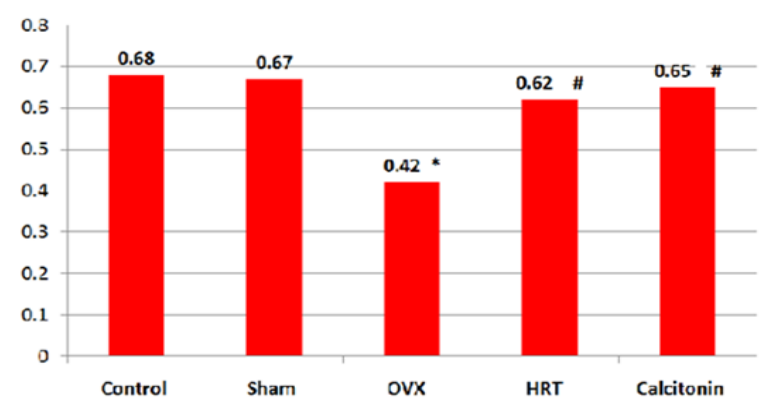

Histogram 4: Showing the mean area percent of $\mathrm{Bcl} 2$ reaction in chondrocyte cytoplasm of the studied groups

\section{DISCUSSION}

$\mathrm{OA}$ is a degenerative joint disease that proceeds slowly and develops over years. When the clinical characteristics of OA (e.g. pain, loss of mobility and radiological narrowing of the joint space) manifest, the actual changes in articular cartilage and subchondral bone would have started some time before ${ }^{[16]}$.

This study was performed to compare the effect of HRT versus calcitonin administration on articular cartilage of the knee joint in murine model of hormonal depletion induced by ovariectomy. This comparison included histological, immunohistochemical and morphemtric studies.

In the present study, examining the knee joint of the control group in H\&E stained sections revealed normal histological architecture of the articular cartilage, smooth articular surface with no covering perichondrium ${ }^{[17]}$.

Osteoarthritic rats in this study showed disruption of the articular cartilage and chondrocytes appeared vacuolated and degenerated. Previous studies enhanced that a decrease in matrix staining, followed by changes in cellularity were the earliest histological abnormalities detected in OA, whereas injury to the cartilage structure were only prominent at advanced $\operatorname{stages}^{[18]}$. Similar findings were reported and demonstrated by the significant decline of serum alkaline phosphatase levels in OA which is considered a gross marker of bone turnover ${ }^{[19]}$.

In the present study, the thickness of the articular cartilage was significantly decreased in group III (8weeks post OVX) compared with control group. Other findings included superficial fibrillation, chondrocyte proliferation and hypertrophy, as stated in classification of $\mathrm{OA}$ severity ${ }^{[20}$ and 21$]$.

The optical density of Alcian blue reaction in chondrocyte cytoplasm as well as those of PAS reaction in cartilage matrix was significantly decreased in group III (8w OVX) compared with control group. Our results agreed with the histological changes in the articular cartilage of OA in the canine model that showed chondrocyte clusters in regions of degenerated matrix with moderate lack of proteoglycans $^{[22]}$.

In cartilage, the extracellular matrix is composed of two main structural elements: collagen type II and aggrecan. There is a steady state between the synthesis and the degradation of aggrecan but in OA accelerated proteolytic cleavage is observed ${ }^{[23]}$. When aggrecan is split, the carboxy-terminal tail of the protein containing the glycosaminoglycans diffuses out of the cartilage and water is no longer retained. Thus, the structural integrity of the cartilage matrix is affected ${ }^{[24]}$. This explains the areas of rarefied and non homogenous matrix appearance in the OA group, and possible variation in the other groups.

Loss of matrix colouration by Safranin O or Alcian Blue was previously stated as an evident feature. Under specific conditions, these stains can be indicative of 
well-established cartilage matrix proteoglycan depletion. Permanent matrix staining lack is associated with inclusive superficial zone cell death. Reversible matrix staining lack is characteristic of the effects of proteolytic enzymes which may be obtained either from cartilage or from synovium ${ }^{[25]}$.

Our current study showed a negative Bcl2 expression in the cytoplasm of chondrocytes of the articular cartilage of osteoarthritic groups. The mean area $\%$ of Bcl-2 immunostaining in chondrocyte cytoplasm was significantly decreased in subgroups III ( 8 weeks post OVX) compared with control group, indicating chondrocyte apoptosis. It was showed apoptotic cells in superficial and middle zones of cartilage in anterior cruciate ligament ${ }^{[26]}$. Moreover, nitric oxid (NO) production was increased during the early phases of OA, which led to chondrocyte apoptosis, and may have contributed to the pathogenesis of cartilage degradation ${ }^{[27]}$.

In the current study the thickness of the articular cartilage was significantly increased in group IV (8weeks post HRT) compared with group III (8weeks post OVX). There was increased cellular population of articular cartilage with preserved subchondral bone. Similar findings were reported that HRT had shown substantial effect in preventing cartilage degeneration and bone turnover ${ }^{[5]}$.

Estrogen can affect the homeostasis of articular cartilage by modifying the expression/production of different molecules such as several growth factors, matrix metalloproteinases, reactive oxygen species and inflammatory cytokines. In vivo surveillance indicated that inhibition of subchondral bone turnover is also portion of the mechanisms by which oestrogen (and all antiresorptive agents) can protect against joint destruction ${ }^{[28]}$.

Oestrogen appears to have a potent protective effect on chondrocytes in vitro. It found that $17 \beta$-oestradiol suppressed doxorubicin-induced apoptosis by blocking volume-sensitive $\mathrm{Cl}-$ influx in rabbit articular chondrocytes $^{[29]}$. In another study, 17 $\beta$-oestradiol treatment prohibited injury- associated cell death and glycosaminoglycan release in articular cartilage explants, suggesting that $17 \beta$-oestradiol may be useful for treating either cartilage-related sports injuries or $\mathrm{OA}^{[30]}$. In rabbit articular chondrocytes, 17 $\beta$-oestradiol has been shown to upregulate collagen type II expression by receptors as Sp1/3, Sox-9, and ERa ${ }^{[31]}$

Group IV that received HRT for 8 weeks post OVX revealed mild increase in cytoplasmic staining of some chondrocytes and their extracellular matrix that was confirmed by positive immunoreactivity and morphometric results.

Research evaluated the association between the cartilage and bone changes of the OA patients affected by sex hormones depletion. They applied the biochemical markers and histological results of cartilage and bone turnover. The combined oestrogen and progesterone therapy would be more effective than administering oestrogen alone in suppressing the progression of $\mathrm{OA}^{[32]}$

In our study, the experimental group that received calcitonin showed an improvement in histological and immunohistochemical results in the form of an increase in cartilage and subchondral bone thickness with hypercellularity of the chondrocytes, indicating preservative activity.

Another study investigated the protective and therapeutic roles of salmon calcitonin on the articular cartilage of rabbits' knees. They were treated immediately after surgery with salmon calcitonin and killed at 4 weeks and 8 weeks post surgery respectively. Calcitonin groups showed smooth articular surface and less subchondral cystic formation than placebo groups. Normal distribution of chondrocytes or hypercellularity was observed in areas of mild osteoarthritic (OA) changes in the calcitonin groups indicating regeneration ${ }^{[33]}$.

In the current work, there was an increase in cartilage thickness in some sites in calcitonin groups. Other studies showed that within 4 weeks following OVX induced chondral damage; an increased synthesis of matrix PGs was observed, representing an apparent attempt to repair the damaged tissue especially when associated with antiresorptive agents as calcitonin ${ }^{[34]}$.

In our work, the calcitonin group showed increase in the optical density of Alcian blue reaction in chondrocyte cytoplasm and PAS reaction in cartilage matrix.

These results were agreed with those of other investigators, who detected the clinical utility of $\mathrm{sCT}$, principally due to its inhibitory effect on osteoclastic bone resorption, management of mineral metabolism, and antinociceptive properties. The increased absorption of PAS and Alcian blue stains indicated the high anabolic phase of the chondrocytes including restoration of mucopolysacharides and acidic-mucopolysaccharides. The chondroprotective effect of sCT may be both of its direct influence on chondrocytes and the long-standing influence on bone resorption ${ }^{[35]}$.

PAS and Alcian blue staining were weak in the OA groups while increased absorption in the calcitonin group revealed high anabolic activity. In prophylactic phases, salmon calcitonin appeared to inhibit the progression of osteoarthritis by increasing the layers of hyaline cartilage. In therapeutic stages, the hormone had a curative effect by decreasing the subchondral bone loss and regenerating the hyaline cartilage ${ }^{[36]}$.

Calcitonin dose dependently inhibited action of collagenase and phospholipase A2 in human OA articular chondrocytes. Calcitonin encourages growth of articular cartilage and maturation of cartilage plate. Calcitonin opposes the progression of joint lesions in clinical models, both traumatic and non-traumatic ${ }^{[11]}$.

Several lines of evidence suggested direct anabolic effects of calcitonin on articular chondrocytes, leading 
to increase proteoglycan synthesis. The anticatabolic effects of calcitonin were found to include induction of cAMP, resulting in mitigation of MMP-mediated cartilage degradation ${ }^{[37]}$. In vitro, calcitonin acts on osteoblasts to increase their proliferation and activity of their alkaline phosphatase which is associated with the increased synthesis and deposition of bone matrix collagen. It also diminshed cartilage erosion and prevented cartilage glycosaminoglycan loss in experimental $\mathrm{OA}^{[38]}$.

Calcitonin has else been found to increase the articular cartilage due to activation of ornithine decarboxylase, an enzyme that is important for the production of proteins ${ }^{[39]}$. Calcitonin significantly reduced the cartilage degradation and has affirmative effects on and bone structure. It proved by the biochemical markers CTX-I and CTX-II (C-terminal telopeptide of type I and II collagen $)^{[40]}$.

It could be concluded that OVX causes severe changes in articular cartilage and these changes are more evident with time. HRT had a significant effect in prevention of cartilage degradation in OVX model of OA. It appears to play a cytoprotective role in the articular cartilage affected by OVX and can be considered as an efficient preventive agent in OA. Despite nearly similar results of both HRT and calcitonin in prevention of cartilage degradation, the risks of HRT exceed its benefits, while the side effects of calcitonin are minimal. So calcitonin could be recommended more than HRT. Longer experimental periods, different doses and different routes of calcitonin administration may be recommended to reach best results. Further work is needed to detect therapeutic effect of calcitonin,

\section{CONFLICTS OF INTEREST}

There are no conflicts of interest.

\section{REFERENCES}

1. Page CJ, Hinman RS, Bennell K L: Physiotherapy management of knee osteoarthritis. Int J Rheum Dis. (2011) 14:145-51.

2. Nishimura A, Hasegawa $M$, Kato $K$, Yamada $\mathrm{T}$, Uchida A et al: Risk factors for the incidence and progression of radiographic osteoarthritis of the knee among Japanese Int Orthop.(2011) $35: 839-43$.

3. Terzi H, Çırpan T, Terzi R, Yeniel AO, Aktuğ H et al: osteoprotective effect of hormone therapy on bone microarchitecture before impaired bone mineral density in ovariectomized rats. J Turk GerGynecol Assoc. (2012) 13(4): 261-6.

4. Engdahl C C, Jochems $\mathrm{S} \mathrm{H}$, Windahl A E, Borjesson $\mathrm{C}$, Ohlsson $\mathrm{H}$ et al: Amelioration of collagen-induced arthritis and immune-associated bone loss through signaling via estrogen receptor alpha, and not estrogen receptor beta or $G$ proteincoupled receptor 30. Arthritis and Rheumatism. (2010) 62(2): 524-33
5. Yang J H, Kim J H, Deuk-Soo Lim D S and Oh K $\mathrm{J}$ : Effect of Combined Sex Hormone Replacement on Bone/Cartilage Turnover in a Murine Model of Osteoarthritis. Clinics in Orthopedic Surgery. (2012) 4: 234-41.

6. Maricic MJ: Oral calcitonin. CurrOsteoporos Rep. (2012) 10(1):80-5.

7. Ryan SM, McMorrow J, Umerska A, Patel $\mathrm{HB}$, Kornerup $\mathrm{KN}$ et al: An intra-articular salmon calcitonin-based nanocomplex reduces experimental inflammatory arthritis. J Control Release. (2013) 167(2):120-9.

8. Mero A, Campisi M, Favero M, Barbera C, Secchieri $\mathrm{C}$ et al: A hyaluronic acid-salmon calcitonin conjugate for the local treatment of osteoarthritis: chondro-protective effect in a rabbit model of early OA. J Control Release. (2014)187:30-8.

9. Sondergaard B C, Catala-Lehnen P, Huebner A K, Bay-JensenT,SchinkeK et al : Mice overexpressing salmon calcitonin have strongly attenuated osteoarthritic histopathological changes after destabilization of the medial meniscus. Osteoarthritis and Cartilage. (2012) 20 (2): 136-43.

10. Bhandari K H, Newa M, Chapman J and Doschak M R: Synthesis, characterization and evaluation of bone targeting salmon calcitonin analogs in normal and osteoporotic rats. J Controlled Release. (2012) 158:44-52.

11. Nielsen R H, Bay-Jensen A, Byrjalsen I andKarsdal M A: Oral salmon calcitonin reduces cartilage and bone pathology in an osteoarthritis rat model with increased subchondral bone turnover.Osteoarthritis and Cartilage. (2011) 19 (4): 466-73.

12. Kiernan J A: Histological and histochemical methods:theory and practice. $3^{\text {rd }}$ ed., Arnold Publisher, London, New York \&New Delhi. (2001) P: 111-62.

13. Bancroft J D \& Gamble M: Theory and practice of histological techniques, $5^{\text {th }}$ edition, Churchill Livingstone, New York, London. (2008) p. 153-9.

14. García-SáezA J: The secrets of the Bcl-2 family. Cell Death and Differentiation. (2012) 19(11):1733-40.

15. EmsleyR, Dunn G and White I R: Mediation and moderation of treatment effects in randomized controlled trials of complex intervention. State Methods Med Res. (2010) 19: 237-70.

16. Johnson VL and Hunter DJ: The epidemiology of osteoarthritis. BestPract Res ClinRheumatol. (2014) 28(1):5-15.

17. van der Kraan P M and van den Berg W B: Chondrocyte hypertrophy and osteoarthritis: role in initiation and progression of cartilage degeneration? Osteoarthritis Cartilage. (2012) 20(3):223-32. 
18. Heidari B: Knee osteoarthritis prevalence, risk factors, pathogenesis and features: Part ICaspian J Intern Med. (2011) 2(2): 205-12.

19. SharmaAR,Jagga S, Lee S, and Nam J: Interplay between Cartilage and Subchondral Bone Contributing to Pathogenesis of steoarthritis. Int J MolSci. (2013)14(10): 19805-30.

20. Pearson R G, Kurien T, Shu K S and Scammell B E: Histopathology grading systems for characterisation of human knee osteoarthritis-reproducibility, variability, reliability, correlation, and validity. Osteoarthritis Cartilage. (2011)19(3):324-31.

21. Rout R, McDonnell S, Benson R, Athanasou N,Carr Aet al: The histological features of anteromedialgonarthrosis-the comparison of two grading systems in a human phenotype of osteoarthritis. Knee. (2011) 18:172-6.

22. Longo U G, Loppini M, Fumo C, Rizzello G, Khan W S et al: Osteoarthritis: New Insights in Animal Models. The Open Orthopaedics Journal. (2012)6(3): 558-63.

23. Roughley P J and Mort J S: The role of aggrecan in normal and osteoarthritic cartilage. J ExpOrthop. (2014)1(1):8-19.

24. Mort J S, Geng Y, Fisher W D and Roughley $\mathrm{P}$ J: Aggrecan heterogeneity in articular cartilage from patients with osteoarthritis. BMC MusculoskeletDisord (2016) 18:17-89.

25. Pauli C, Whiteside R, Heras F L, Nesic D, Koziol $\mathrm{J}$ et al: Comparison of cartilage histopathology assessment systems on human knee joints at all stages of osteoarthritis development. Osteoarthritis Cartilage. (2012) 20:476-85.

26. Hootman J M and Albohm M J: Anterior cruciate ligament injury prevention and primary prevention of knee Osteoarthritis.J Athletic Training. (2012) 47(5): 589-90.

27. Hwang H S and Kim H A: Chondrocyte Apoptosis in the Pathogenesis of Osteoarthritis.Int J MolSci. (2015) 16(11): 26035-54.

28. Wang W, Wang L, Xu Z, Yin Y, Su J, Niu X, Cao X: Effects of estradiol on reduction of osteoarthritis in rabbits through effecton matrixmetalloproteinase proteins. IranJBasic. (2016) 19:310-5.

29. Kumagai K, Imai S, Toyoda F, Okumura N, Isoya E et al 17ß-Oestradiol inhibits doxorubicin-induced apoptosis via block of the volume-sensitive $\mathrm{Cl}$ current in rabbit articular chondrocytes. $\mathrm{Br} \mathrm{J}$ pharmacol. (2012):166: 702-20.

30. mgenberg J, Rolauffs B, Grodzinsky A J, Schünke $\mathrm{M}$ and Kurz B: Estrogen reduces mechanical injury- related cell death and proteoglycan degradation in mature articular cartilage independent of the presence of the superficial zone tissue. Osteoarthritis Cartilage. (2013) 21(11):1738-45.

31. Maneix L, Servent A, Porée B, Ollitrault D, Branly $\mathrm{T}$ et al: Up-regulation of type II collagen gene by $17 \beta$-estradiol in articular chondrocytes involves $\mathrm{Sp} 1 / 3$, Sox-9, and estrogen receptor $\alpha . J$ Molecular Medicine. (2014) 92:1179-200.

32. Schroeppel J P, Crist J D, Anderson H C and Wang $\mathrm{J}$ : Molecular regulation of articular chondrocyte function and its significance in osteoarthritis HistolHistopathol. (2011)26(3):377-94.

33. Segovia-Silvestre T, Bonnefond C, Sondergaard B C, Christensen T, Karsdal M A et al: Identification of the calcitonin receptor in osteoarthritic chondrocytes. BMC Research Notes. (2011)4: 407-16.

34. eichtahl A J, Wluka A E, Wijethilake P, Wang U, Ghasem-Zadeh A et al: A mechanism for early knee osteoarthritis. Arthritis Research \& Therapy. (2015)17:207-18.

35. Karsdal M A, Byrjalsen I,Alexandersen P, Bihlet A, Andersen J Ret al: Treatment of symptomatic knee osteoarthritis with oral salmon calcitonin: results from two phase 3 trials. Osteoarthritis and Cartilage. (2015) 23(4): 532-43.

36. Wen Z H, Tang C C, Chang Y C, Huang S Y, Lin Y Yet al: Calcitonin attenuates cartilage degeneration and nociception in an experimental rat model of osteoarthritis: role of TGF- $\beta$ in chondrocytes. Sci. Rep. (2016) 6: 28862-73.

37. Greco K V, Nalesso G, Kaneva M K, SherwoodJ, Iqbal A J et al: analyses on the mechanisms that underlie the chondroprotective properties of calcitonin. Biochemical Pharmacology. (2014)91(3): 1348-58.

38. Vasaghi A, Karimizadeh $M$ and Ashraf A: Calcitonin Injection and Functional Status of Females With Knee Osteoarthritis. J Archives in Military Medicine. (2016) 4(3): 38493- 8.

39. Kyrkos M J, Papavasiliou K A, Kenanidis E, Tsiridis E, Sayegh F E et al: Calcitonin delays the progress of early-stage mechanically induced osteoarthritis. In vivo, prospective study. Osteoarthritis and Cartilage. (2013) 21(7): 973-80.

40. Karsdal M A, Bay-Jensen AC, Lories R J, Abramson S, Spector $\mathrm{T}$ et al: The coupling of bone and cartilage turnover in osteoarthritis: opportunities for boneantiresorptives and anabolics as potentialtreatments? Ann Rheum Dis. (2013)73(2):336-48. 


\title{
دراسة هستولوجية لتاثير الوقائي للكالسيتونين و العلاج الهرموني الاستبدالي علي الفصال العظمي المستحث تجريبيا
}

\author{
فاتن رياض عمر عثمان، ميرا فاروق يوسف، سمراء حسين عبد القوي، علا اسماعيل مجاهد \\ قسم الهستولوجيا وبيولوجيا الخلية، كلية الطب، 'جامعة القاهزة ـ ‘جامعة بني سويف
}

الخلفيه: يعتبر الفصال العظمي أكثر الأمر اض التنكسية المرتبطة بالعمر شيوعًا ، والتي ترتبط بالإناث بعد انقطاع الطمث.

الهدف من العمل: لمقارنه تاثير العلاج الهرموني الاستبدالي والكالسيتونين علي غضروف مفصل الركبه لنموزج الجرذان المستأصلة المبايض . المواد والألساليب: هذه الدر اسه نفذت بالفحص علي سته وثلاثون انثي الجرذان البيضاء البالغه وقسموا الي خمس مجمو عات :المجموعه الاولي( الضابطه )و المجمو عه الثانيه تعرضت لعمليه فتح بطن و اعاده اغلاقها و المجمو عه الثالثه تعرضت لعمليه استئصال مبايض المجمو عه الر ابعه ضمت ثمانيه جرذان و وتعرضت لعمليه استنصسال مبايض وتم اعطائهم العلاج الهرموني الاستبدالي كل يوم من بعد العمليه ا مل لكل كجم(0.2 مل) لكل يوم عضليا( لثمان اسابيع).المجمو عه الخامسه تعرضت لعمليه استئصال مبايض وتم اعطائهم الكالستونين كل يوم من بعد العمليه 2 وحده مل لكل كجم(0.04 مل) كل يوم تحت الجلدو تمت التضحية بهم بعد ثمان اسابيع. الغضروف المفصلي لمفصل الركبه وضعت العينات المتضمنه الغضروف المفصلي لمفصل الركبه في محلول حمض الهيدروليك لنزع الكالسيوم وتم تجهيز هم لمقاطع البر افين وصبغهم بصبغة الهيماتوكسلين و الإيوسين وصبغة حمض البيروديك الثيف وصبغة الالثين الزرقاء و الدلالات المناعية و أقيمت در اسات كميه قياسيه. •النتائج: أدت عملية استئصسال المبيض إلى انتكاس وموت الخلايا المبرمج وتدهور البنية الطبيعية للغضروف المفصلي ، مع انخفاض تفاعل صبغة حمض البيروديك الثيف و انخفاض صبغة الالثين الزرقاء وضعف الدلالات المناعية للخلايا عند مقارنته بالمجمو عة الضابطة والثاملة. الكالسيتونين و العلاج الهرموني الاستبدالي بعد استنصسال المبايضز في الغالب منع هذه التغييرات. الاستتتاج: لقد استتنج ان عملية استنئصال المبيضى تسبب تغير ات شديده في الغضروف المفصلي ويزيد مع الوقت. العلاج الهرموني الاستبدالي له تأثثير كبير في الوقاية من تدهور الغضروف في نموذج الفصال العظمي بعد استنصسال المبيض. يحسن الكالسيتونين بشكل كبير البنية النسيجية للغضروف المفصلي. لذلك الكالسيتونين له تأثثير كبير في الوقاية من تدهور الغضروف في نموذج الفصال العظمي بعد استئصال المبيض. يمكن اعتباره كعامل علاجي محتمل للفصال 